\title{
Efektivitas Ekstrak Daun Afrika (Vernonia amygdalina) Secara Topikal Terhadap Kepadatan Kolagen dalam Penyembuhan Luka Insisi Pada Tikus Putih (Rattus norvegicus)
}

\section{(EFFECTIVITY OF BITTER LEAF EXTRACT (Vernonia amygdalina) TOPICALLY ON COLLAGEN DENSITY ON INCISION WOUND HEALING IN RATS (Rattus norvegicus))}

\author{
Rona Taufiqul Rachmanita ${ }^{1 *}$, Hardany Primarizky ${ }^{2}$, Faisal Fikri ${ }^{3}$ Boedi Setiawan², \\ Bodhi Agustono ${ }^{4}$, Amung Logam Saputro ${ }^{2}$ \\ ${ }^{1}$ Bachelor of Veterinary Medicine, \\ ${ }^{2}$ Department of Veterinary Clinic, \\ ${ }^{3}$ Department of Basic Veterinary Science, \\ ${ }^{4}$ Department of Animal Husbandry, \\ Faculty of Veterinary Medicine, Universitas Airlangga, \\ UNAIR C-Campus Mulyorejo, Surabaya, Jawa Timur, Indonesia, 60115 \\ Telp. (031)5993016, Fax. (031)5993015 \\ *Corresponding author: rona.taufiqul.r-2014@ fkh.unair.ac.id
}

\begin{abstract}
Abstrak
Tujuan dari penelitian ini adalah untuk mengetahui efektivitas pemberian ekstrak daun Afrika (Vernonia amygdalina) secara topikal terhadap kepadatan kolagen dalam penyembuhan luka insisi pada tikus putih (Rattus norvegicus). Dua puluh ekor tikus putih dibagi secara acak ke dalam lima kelompok, yaitu kontrol negatif (K-) yang diberi basis salep, kontrol positif $(\mathrm{K}+)$ yang diberi salep povidone iodine $10 \%$, kelompok perlakuan (P1, P2, P3) yang diberi perlakuan dengan salep ekstrak daun Afrika 16,8\%, 28\%, dan 39,2\%. Perlakuan diberikan secara topikal pada lokasi luka insisi sebanyak dua kali sehari selama empat belas hari. pada hari keempat belas tikus dieuthanasi dan daerah insisi dieksisi untuk preparasi histopatologi. Data yang didapatkan dianalisis menggunakan Kruskal-Wallis dengan SPSS 20. Hasil uji menunjukkan $p=0,077$ yang berarti tidak terdapat perbedaan yang nyata $(\mathrm{p}>0,05)$ antara keseluruhan perlakuan. Berdasarkan hasil tersebut rata-rata P1 menunjukkan hasil skoring kepadatan kolagen tertinggi dibandingkan perlakuan yang lain. Kesimpulan penelitian ini yaitu bahwa daun Afrika (Vernonia amygdalina) tidak efektif meningkatkan kepadatan kolagen dalam penyembuhan luka insisi pada tikus putih (Rattus norvegicus).
\end{abstract}

Kata kunci: Vernonia amygdalina, penyembuhan luka, kepadatan kolagen

\begin{abstract}
The aim of this research was to determine the effectiveness of bitter leaf(Vernonia amygdalina) extract topically can accelerate the density of collagen on incision wound healing in rats (Rattus norvegicus). Twenty male rats were randomly devided into five groups, there were negative control $(K-)$ treated with ointment base, positive control $(\mathrm{K}+)$ treated with povidone iodine $10 \%$ ointment, treated groups $(P 1, P 2, P 3)$ treated with bitter leaf extract ointment 16,8\%; 28\%; and 39,2\%. Treatment had been given directly on the subcutan incision area topically twice a day for fourteen days. On the day fourteen of this research samples were dissected and taken to the skin organ preparation for histophatology test. The data of histopatological appereance were processed with Kruskal-Wallis using SPSS 20. The result showed is $p=0,077$ that is no signicantly different $(p>0,05)$ between treatment. Based on the result the average P1 has highest density of collagen than the others treatment. This research concluded that bitter leaf (Vernonia amygdalina) can not accelerate density of collagen on incision wound healing in rats.
\end{abstract}

Key words: Vernonia amygdalina, wound healing, collagen density 


\section{PENDAHULUAN}

Kulit memiliki peranan yang penting dalam melindungi tubuh dari benda-benda asing seperti parasit, mikrorganisme, dan jamur, pengatur keseimbangan air dan elektrolit, sensasi, termoregulasi, perlindungan dari sinar ultraviolet (Budiman dan Derick, 2015).

Kulit sering mengalami luka yang dapat menyebabkan kerusakan jaringan epitel dan terputusnya kesatuan struktur anatomi kulit normal (Nabeela, 2017). Luka merupakan hilangnya kontinuitas jaringan anatomis sehingga dapat menyebabkan gangguan selular.

Luka yang terjadi akan direspon oleh tubuh untuk segera dilakukan proses penyembuhan. Pengobatan yang sering dilakukan adalah menggunakan povidone iodine $10 \%$, namun kandungannya sebagai antimikroba dapat menghambat pembentukan fibroblas. Alternatif pengobatan lainnya diperlukan dengan menggunakan daun Afrika. Ekstrak daun Afrika mengandung trepenoid, saponin, flavonoid, alkaloid, dan vitamin $\mathrm{C}$ yang dapat membantu mempercepat proses penyembuhan luka. Ekstrak daun Afrika efektif dalam meningkatkan sel fibroblas, epitelisasi, dan menurunkan sel radang $30 \%$ lebih baik dibandingkan tanpa perlakuan.

Penelitian yang telah dilakukan hanyalah sebatas penggunaan daun Afrika terhadap luka eksisi dan belum pernah dilakukan pada luka insisi dengan dosis tertentu dalam sediaan unguentum. Penelitian ini sangat penting untuk dilakukan untuk menyempurnakan penelitian yang sebelumnya telah dilakukan oleh Eyo et al., (2014) sehingga penggunaan sediaan ekstrak daun Afrika akan lebih mudah diaplikasikan secara topikal, serta mengurangi efek zat kimia yang selama ini telah kita gunakan dalam pengobatan luka.

Berdasarkan latar belakang tersebut maka perlu dilakukan penelitian tentang efektivitas ekstrak daun Afrika (Vernonia amygdalina) terhadap kepadatan kolagen pada luka insisi tikus putih (Rattus norvegicus).

\section{METODE PENELITIAN}

\section{Ijin Etik Hewan Coba}

Penelitian ini telah melalui uji etik penelitian hewan coba dengan sertifikat etical clearance nomor 783-KE.

\section{Alat dan Bahan Penelitian}

Alat dan bahan penelitian ini adalah tikus putih, daun Afrika, salep povidone iodine 10\% (Betadine ${ }^{\circledR}$ ), methanol $100 \%$, aquadest, Adeps Lanae, Vaselin Flavum, Ketamine, Xylazine, air minum, buffer formaline 10\%, alkohol $70 \%$, wound dressing, kasa steril, kapas steril dan pakan hewan coba dengan kandungan protein 4\% serta lemak 5\% dan kalori $3800 \mathrm{kcal} / \mathrm{g}$, kandang tikus, tempat minum, tempat pakan, litter dari serbuk kayu, spuit $1 \mathrm{cc}$, masker, glove, alat pencukur, blade no. 14, scalpel no. 3 , pinset anatomis, gelas beaker $100 \mathrm{ml}$, gelas ukur 100 $\mathrm{ml}$, pipet Pasteur, timbangan analitik (Ohaus ${ }^{\circledR}$ PA 214), kertas saring, mortar, stamper, kaca arloji, sudip, spaltel penyu, rotatory evaporator, pengaduk, vacuum pump, Buchner, pot salep, penggaris, mikroskop cahaya (Olympus ${ }^{\circledR} \mathrm{CX} 23$ ), dan kamera.

\section{Pembuatan Ekstrak Vernonia amygdalina}

Daun Afrika segar yang diperoleh dicuci dengan air bersih dan dikeringkan di bawah sinar matahari hingga mengering. Daun Afrika setelah itu digiling dengan penggiling hingga menjadi serbuk halus. Serbuk tersebut kemudian ditimbang $100 \mathrm{~g}$ dan dimaserasi dengan methanol $100 \%$ sebanyak $500 \mathrm{ml}$. Larutan dicampur dengan pengaduk konstan selama 3 jam sekali dan ditunggu 2 hari pada suhu ruang, lalu larutan disaring menggunakan Buchner dan vacuum pump. Filtrat yang didapat diuapkan menggunakan rotatory evaporator dengan kecepatan $80 \mathrm{rpm}$ dan suhu $90^{\circ} \mathrm{C}$ hingga didapatkan ekstrak kental. Ekstrak yang didapat lalu dilarutkan dalam sediaan unguentum menggunakan vaseline flavum dan adeps lanae dengan tiga konsentrasi ekstrak daun Afrika yaitu $16,8 \%, 28 \%$, dan $39,2 \%$.

\section{Perlakuan}

Hewan coba tikus putih (Rattus norvegicus) diadaptasikan dengan lingkungan selama tujuh 
hari sebelum perlakuan dimulai. Tikus putih dianastesi menggunakan kombinasi Ketamine 50 $\mathrm{mg} / \mathrm{kgBB}$ dan Xylazine $5 \mathrm{mg} / \mathrm{kgBB}$ (Suckow et $a l ., 2006)$ secara intramuskular. Tikus kemudian dicukur bulunya pada bagian punggung seluas 3 $\mathrm{cm}$ x 2,5 $\mathrm{cm}$ dan pada daerah tersebut dilakukan insisi dengan menggunakan scalpel dengan panjang $2 \mathrm{~cm}$ hingga bagian subcutan (Asali, 1993).

Tikus putih yang telah diinsisi dibagi dalam lima kelompok perlakuan yaitu kelompok kontrol negatif (K-) diberi basis salep, kelompok kontrol positif $(\mathrm{K}+)$ diberi salep povidone iodine $10 \%$ (Betadine $^{\circledR}$ ), kelompok perlakuan P1 diberi salep ekstrak daun Afrika 16,8\%, kelompok perlakuan P2 diberi salep ekstrak daun Afrika 28\%, dan kelompok perlakuan P3 diberi salep ekstrak daun Afrika 39,2\%. Salep diberikan secara topikal sehari dua kali selama 14 hari. Hari keempat belas tikus dieuthanasia dengan metode dislokasio servikalis, kemudian kulit sekitar daerah perlukaan dieksisi seluas $3 \times 3$ $\mathrm{cm} 2$. Jaringan yang diambil difiksasi dalam larutan buffer formalin 10\% untuk kemudian dibuat preparat histopatologi pewarnaan Haematoxylin-Eosin (HE).

\section{Metode Skoring}

Perubahan yang diamati melalui skoring histopatologi kepadatan kolagen pada daerah luka menurut Novriansyah (2008) berdasarkan perhitungan 4 lapang pandang, pada obyek pembesaran 400 kali berikut ini:

\begin{tabular}{cl}
\hline Skor & \multicolumn{1}{c}{ Deskripsi } \\
\hline+0 & $\begin{array}{l}\text { Tidak ditemukan adanya serabut } \\
\text { kolagen pada daerah luka }\end{array}$ \\
+1 & $\begin{array}{l}\text { Kepadatan serabut kolagen pada } \\
\text { daerah luka rendah (25\%) }\end{array}$ \\
+2 & $\begin{array}{l}\text { Kepadatan serabut kolagen pada } \\
\text { daerah luka sedang (50\%) }\end{array}$ \\
+3 & $\begin{array}{l}\text { Kepadatan serabut kolagen pada } \\
\text { daerah luka rapat (75\%) }\end{array}$ \\
+4 & $\begin{array}{l}\text { Kepadatan kolagen pada daerah luka } \\
\text { sangat rapat (100\%) }\end{array}$ \\
\hline
\end{tabular}

\section{Analisis Data}

Data perubahan histopatologi dianalisis menggunakan uji Kruskal-Wallis dilanjutkan dengan uji beda Mann-Whitney- $U$ apabila terdapat perbedaan nyata dengan derajat kemaknaan $\mathrm{p}<0,05$. Analisis data dilakukan dengan program komputer Statistical Packed for Social Science 20 (SPSS) for Windows (AlArief, 2016).

\section{HASIL DAN PEMBAHASAN}

Data skoring dianalisis menggunakan Kruskal-Wallis dengan hasil $\mathrm{p}=0,077$ yang menunjukkan tidak terdapat perbedaan yang nyata $(p>0,05)$ pada seluruh kelompok perlakuan. Uji data statistik tidak dilanjutkan ke uji Mann-Whitney karena tidak adanya perbedaan yang signifikan pada seluruh perlakuan. Hasil analisis data skoring kepadatan kolagen disajikan pada tabel 1 .

Tabel 1. Rata-rata dan simpangan baku kepadatan kolagen kulit tikus putih pada setiap perlakuan

\begin{tabular}{lc}
\hline \multicolumn{1}{c}{ Perlakuan } & $(\mathbf{X} \pm$ SD) \\
\hline K- (kontrol negatif) & $1,88^{\mathrm{a}} \pm 0,629$ \\
K+ (povidone iodine 10\%) & $2,00^{\mathrm{a}} \pm 0,677$ \\
P1 (EDA 16,8\%) & $2,56^{\mathrm{a}} \pm 0,315$ \\
P2 (EDA 28\%) & $1,75^{\mathrm{a}} \pm 0,540$ \\
P3 (EDA 39,2\%) & $1,31^{\mathrm{a}} \pm 0,375$ \\
\hline
\end{tabular}

Kepadatan kolagen dari yang tertinggi hingga terendah yaitu kelompok perlakuan P1, $\mathrm{K}+, \mathrm{K}-, \mathrm{P} 2$ dan terakhir $\mathrm{P} 3$ dengan rata-rata skoring kepadatan kolagen 2,56; 2,00; 1,88; 1,75 ; dan 1,31. Pengobatan yang sering dilakukan untuk menyembuhkan luka ialah menggunakan salep povidone iodine $10 \%$ (Betadine ${ }^{\circledR}$ ), namun menurut Muhammad (2005), povidone iodine $10 \%$ yang memiliki efek antimikroba masih menjadi perdebatan karena dapat menimbulkan efek toksik pada penelitian in vitro tingkat sel. Efek toksik yang ditimbulkan 
menyebabkan sel menjadi rusak dan terjadi apoptosis (Widianto, dkk., 2015).

Daun Afrika memiliki manfaat antibakteri, antikoagulan, anti-inflamasi, analgesik dan antioksidan yang baik sebagai penyembuhan luka. Daun Afrika mengandung flavonoid sebagai antioksidan, saponin sebagai memacu pertumbuhan kolagen dan alkaloid sebagai melawan infeksi mikrobial (Fitri, 2015).
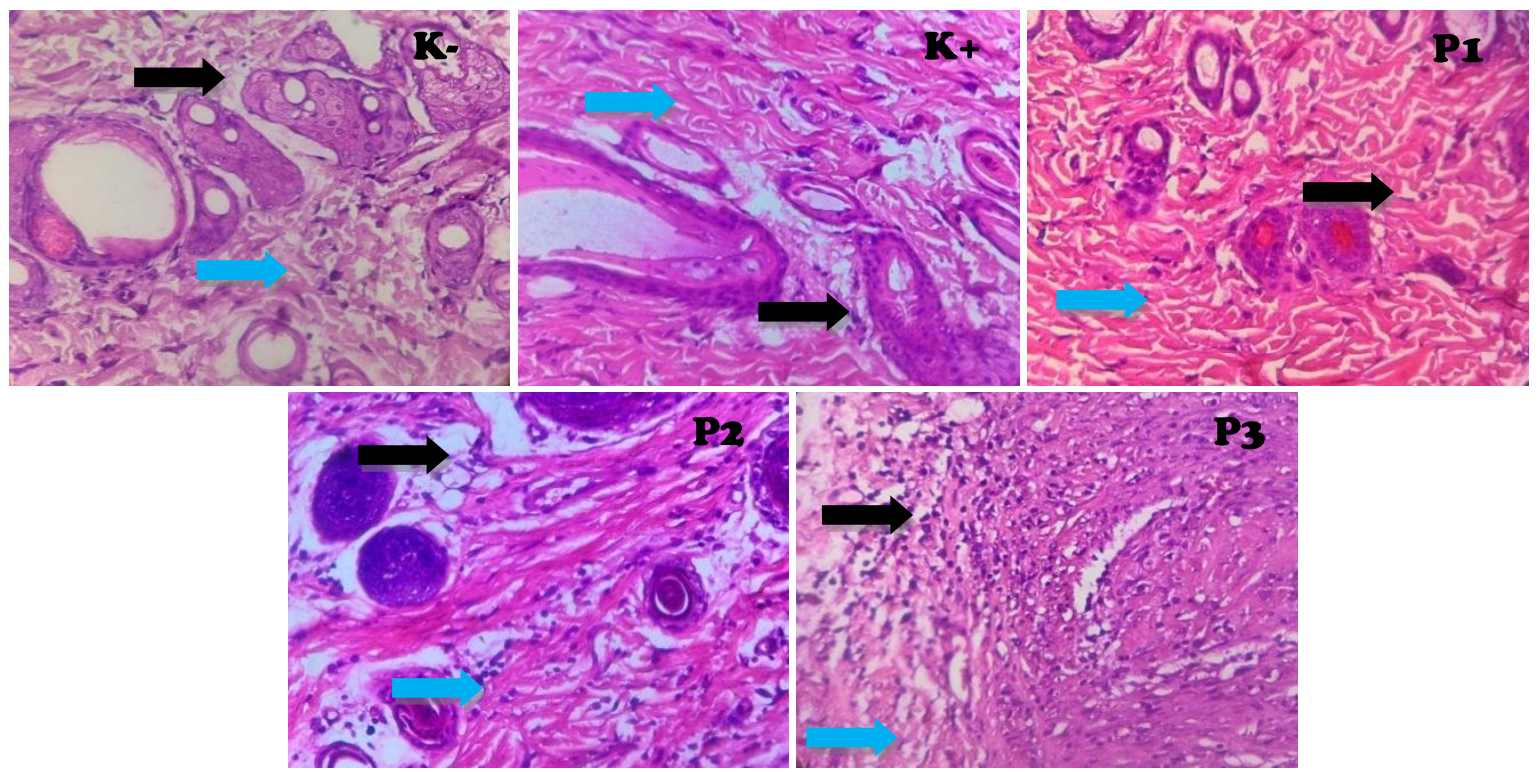

Gambar 1. Gambaran histopatologi tikus putih setiap perlakuan pada hari ke 14 (pewarnaan HE, 400X) yang ditunjukkan oleh sel radang $(\rightarrow)$ dan kolagen $(\rightarrow)$

Pada kelompok perlakuan $\mathrm{K}+$ (salep povidone iodine $10 \%$ ) terjadi sedikit peningkatan rata-rata kepadatan kolagen dibandingkan kelompok perlakuan K- (basis salep) walaupun tidak secara signifikan. Salep povidone iodine $10 \%$ merupakan salah satu obat yang paling sering digunakan dalam pengobatan segala jenis macam luka insisi. Kandungan salep povidone iodine $10 \%$ berfungsi sebagai antimikroba dapat mencegah terjadinya kontaminasi mikroba pada jaringan yang terluka dengan cara menghambat pembentukan protein pada mikroba sehingga mikroba tersebut hancur dan tidak dapat berkembang (Rahmawati, 2014). Povidone iodine $10 \%$ dapat meningkatkan kepadatan kolagen karena fase inflamasi dapat terlewati lebih awal dibandingkan pada kelompok perlakuan kontrol negatif (K-) yang hanya diberi basis salep.

Rata-rata skoring kepadatan kolagen pemberian ekstrak daun Afrika 16,8\% sedikit lebih tinggi dibandingkan kelompok kontrol negatif dan positif (povidone iodine 10\%) namun peningkatannya tidak signifikan. Hasil peningkatan kepadatan kolagen pada dosis ekstrak daun Afrika 16,8\% sesuai dengan teori Nafiu et al., (2016) bahwa ekstrak daun Afrika dapat meningkatkan kepadatan kolagen pada luka. Ekstrak daun Afrika mengandung flavonoid, saponin, dan alkaloid yang mampu meningkatkan kepadatan kolagen.

Kandungan flavonoid dalam ekstrak daun Afrika dapat berfungsi untuk meningkatkan sintesis kolagen, antioksidan sebagai penangkal radikal bebas, dan efek antimikroba (Shanmugam et al., 2010). Flavonoid bekerja mengaktifkan sel $\mathrm{T}$, berdiferensiasi, dan berproliferasi menjadi TH1, TH2, dan TH3. Sel TH3 akan menghasilkan Transforming Growth Factor- $\beta$ (TGF- $\beta$ ) yang dapat memacu proliferasi fibroblas (Dashputre and Naikwade, 2010). Saponin dapat memacu sintesis fibronektin oleh fibroblas, sehingga kolagen yang terbentuk dapat lebih cepat (Nugraha, 2016). Alkaloid dalam daun Afrika memiliki fungsi membantu melawan infeksi mikrobial dan mengurangi rasa sakit (Fitri, 2015). 
Dosis ekstrak daun Afrika 28\% dan 39,2\% skoring kepadatan kolagen menurun dibandingkan kelompok perlakuan negatif (K-), walaupun perbedaannya tidak signifikan. Penurunan kepadatan kolagen dapat disebabkan karena aktifitas sitotoksik dari daun Afrika yang mengandung sesquiterpen lakton yang baik dalam melawan bakteri, namun juga dapat berbahaya bagi jaringan yang sehat (Dalazen et al., 2005).

Kadar flavonoid yang tinggi dapat disebabkan oleh peningkatan kepekatan salep sehingga menurunkan aktivitas antioksidannya (Paramita, 2016). Flavonoid merupakan senyawa fenol yang dapat mengkoagulasi protein sehingga menyebabkan sel membran menjadi lisis (Parwata dan Dewi, 2008). Konsentrasi saponin yang terlalu tinggi menyebabkan peningkatan permeabilitas membran, sehingga sel akan mengalami kematian (Indraswary, 2014). Hal ini dapat menjelaskan bahwa semakin tinggi dosis ekstrak daun Afrika yang diberikan maka efek sitotoksin yang timbul juga menjadi besar.

\section{KESIMPULAN}

Kesimpulan penelitian pemberian ekstrak daun Afrika (Vernonia amygdalina) secara topikal selama 14 hari tidak efektif meningkatkan kepadatan kolagen dalam proses penyembuhan luka insisi pada tikus putih (Rattus norvegicus).

\section{UCAPAN TERIMA KASIH}

Penulis mengucapkan terimakasih kepada kedua orang tua yang telah membiayai penelitian, dosen pembimbing yang memberikan arahan dan masukan bagi penulis, serta rekan mahasiswa yang telah membantu selama penelitian berlangsung.

\section{DAFTAR PUSTAKA}

Al-Arief, M. A. 2016. Rancangan Percobaan. Lentera Jaya Madina. Surabaya. 33-40.
Asali, A. 1993. Pengantar Ilmu Bedah. Fakultas Kedokteran Hewan Universitas Airlangga. Surabaya.

Budiman, I. dan Derick. 2015. Aktivitas Kesembuhan Luka Rimpang Kunyit (Curcuma longa Linn.) Terhadap Luka Insisi pada Mencit Swiss-Webster Jantan Dewasa. Fakultas Kedokteran. Universitas Kristen Maranatha. Bandung.

Dalazen, P., Molon, A., Biavatti, M. W., Kreuger, M. R. O. 2005. Effects of Topical Application of Extract from Vernonia scorpiodes on Excisional Wounds inMice. Rev. Bras. Farmacogn., 15, 82-87.

Dashputre, N. L., Naikwade, N. S. 2010. Preliminary Immunomodulator Activity of Aqueous and Ethanoli leaves extract of Oimum Basilum linn in Mice. International J. PharmTech Res., 2, 1342-1349.

Eyo, J. E., Uzoibiam, B. O., Ogbanya, K. C., Nnaji, T. O. 2014. Comparative Evaluation of Wound Healing Effects of Ocimum gratissimum, Vernonia amygdaline and Zingiber officinalis Extracts on Incision Wound Model in Rats. SILAE, 3, 44-50.

Fitri, N. 2015. Penggunaan Krim Ekstrak Batang dan Daun Suruhan (Peperomia pellucida L.H.B.K) dalam Proses Penyembuhan Luka Bakar pada Tikus Putih (Rattus norvegicus). Jurusan PMIPA Unpati. Ambon. Biopendix, 1(2), 193-203.

Indraswary, R. 2014. Efek Konsentrasi Ekstrak Buah Adas (Foeniculum vulgare Mill.) Topikal pada Epitelisasi Penyembuhan Luka Gingiva Labial Tikus Sprague Dawley in vivo. Fakultas Kedokteran Gigi. Universitas Islam Sultan Agung. Semarang.

Muhammad, A. 2005. Konsep Dasar Sistem Pakar. Penerbit Andi. Yogyakarta. 
Nabeela, S. A. 2017. Efektivitas Gel Ekstrak Daun Binahong (Anrendera cordifolia (Ten.) Steenis) pada Luka Insisi Mencit (Mus musculus) Melalui Pengamatan Panjang Area Luka dan Penyembuhan Luka. Fakultas Kedokteran Hewan Universitas Airlangga. 3.

Nugraha, G. A. F. 2016. Efek Pemberian Ekstrak Etanol $70 \%$ Daun Karamunting (Rhodomyrtus tomentosa (Aiton) Hassk) Topikal terhadap Gambaran Histopatologi Ketebalan Serat Kolagen Penyembuhan Luka Insisi Kulit Tikus Putih Galur Wistar. Fakultas Kedokteran. Universitas Tanjungpura. 10-11.

Paramita, A. 2016. Pengaruh Pemberian Salep Ekstrak Daun Binahong (Anredera cordifolia (Ten) Steenis) Terhadap Kepadatan Kolagen Tikus Putih (Rattus norvegicus) yang Mengalami Luka Bakar [Skripsi]. Fakultas Kedokteran Hewan. Universitas Airlangga. Surabaya. 7-25.

Parwata, I. M. O. A., Dewi, P. F. S. 2008. Isolasi dan Uji Aktivitas Antibakteri Minyak Atsiri dari Rimpang Lengkuas (Alpinia galangal
L.). Jurnal Kimia. Universitas Udayana. Jimbaran, 2(2), 100-104.

Rahmawati, I. 2014. Perbedaan Efek Perawatan Luka Menggunakan Gerusan Daun Petai Cina (Leucaena glauca, Benth) dan Povidone Iodine 10\% dalam Mempercepat Penyembuhan Luka Bersih pada Marmut (Cavia porcellus). Jurnal Wiyata., 1(2), 227 234.

Shanmugam, S., Kumar, T. S., Selvan, K. P. 2010. Laboratory Handbook on Biochemistry. PHI Learning Pvt. New Delhi. 20-23.

Suckow, M. A., Weisbroth, S. H., Franklin, C. L. 2006. The Laboratory Rat. American College of Laboratory. Elsevier Academic Press. USA. 655.

Widianto, B., Rahardjo, Rahajoe, P. S., Susilawati, R. 2015. Pengaruh Chlorhexidine 0,2\% dan Povidone Iodine 10\% pada Luka Terbuka terhadap Sel Radang, Proliferasi Sel, dan Sel Apoptosis. Jurnal Kedokteran Gigi, 6(2), 89-99. 